\title{
K historii tělesné výchovy a sportu v místním sdružení YMCA v Bratislavě v meziválečném období
}

\section{Contribution to the history of physical education and sport in local union of YMCA in Bratislava during interwar period}

\author{
Tomáš Tlustý \\ Pedagogická fakulta Jihočeské univerzity České Budějovice
}

\begin{abstract}
Abstrakt
Stat pojednává o historii tělesné výchovy a sportu v místním sdružení YMCA v Bratislavě v meziválečném období. YMCA prispěla v Bratislavě ke zpopularizování celé řady sportů, z nichž na prvních mistech byly basketbal a volejbal. Kromě nich byly mezi členstvem bratislavské YMCA populární např. stolní tenis, lehká a těžká atletika či ragby. Rovněž výuce plavání a výcviku zachránců tonoucích zde věnovala YMCA velkou pozornost. Tím se snažila predejít každoročním neštěstím na Dunaji. Její činnost v oblasti tělesné výchovy a sportu ještě vzrostla po přestavbě budovy v roce 1927. V př́stavbě se totiž nacházela tělocvična, kterou pak členstvo využívalo především k sportovním hrám v zimním období. Zimní tréninky se pak pozitivně projevily na výkonnosti hráču především v basketbalu a volejbalu. Ani tak se sportovcům bratislavské YMCA nikdy nepodařilo dostat v těchto hrách na republikový vrchol. Ve druhé polovině 30. let začala tělesná výchova a sport v bratislavské YMCA upadat. Po rozpadu Československa v roce 1938 došlo k rozdělení československé YMCA. Ta byla následně na Slovensku zakázána. Po druhé světové válce byla YMCA v Československu obnovena, ale na Slovensku i nadále pưsobila samostatně.
\end{abstract}

\begin{abstract}
The presented article discusses the history of physical education and sport in local YMCA union in Bratislava during interwar period. The YMCA contributed the popularization of sports, especially basketball and volleyball. Besides them for example table tennis, track and field, heavy athletics or rugby were also popular among its members. Education of swimming and lifesaving was also part of the YMCA activity. This was the way they tried to prevent the every-year accidents on the Danube River. Its activity in the field of physical education and sport increased after finishing of outbuilding of the YMCA center in 1927. In this outbuilding gym, which was used by members to practice especially during winter season, was placed. Winter trainings had positive influence on improvement of player's skills especially in basketball and volleyball. Sportsman of the YMCA in Bratislava had never become the republic champions though. In the second half of 1930s the physical education and sport in the YMCA in Bratislava started to be less important. After the split of Czechoslovakia in 1938 the Czechoslovakian YMCA was split as well. After that the YMCA in the Slovakia was prohibited. When the WWII ended, the YMCA in Czechoslovakia was restored, nevertheless in the Slovakia it worked separately.
\end{abstract}

Klíčová slova: YMCA; Bratislava; meziválečné období; sportovní vývoj; výsledky.

Keywords: YMCA; Bratislava; interwar period; sport development; results.

\section{ÚVOD}

Young Men’s Christian Association - Křestanské sdružení mladých mužů je nábožensky orientovaná mezinárodní organizace mládeže s velice širokým spektrem činností, která byla založená Georgem Williamsem v Londýně v roce 1844. K jejímu velkému rozvoji došlo především 
ve Spojených státech amerických, kde byla rovněž její tělovýchovná a sportovní činnost zřejmě nejvíce preferovanou částí celého programu.

Po skončení první světové války došlo zejména díky americkým sekretářům působícím v Evropě k dalšímu šíření organizace YMCA, která si našla cestu i do zemí střední Evropy, mezi kterými bylo i nově vzniklé Československo.

Počátky YMCA v Bratislavě však sahají až do Rakouska-Uherska. V 80. letech 19. století zde existovala skupina mladých mužů, kteří se již hlásili k programu této mezinárodní organizace. ${ }^{1}$ Tato skupina však velice pravděpodobně zanikla před nebo během první světové války.

Do Československa pak YMCA pronikla po první světové válce, a to především díky příslušníkům Čs. legií. Do Bratislavy přišli první členové tohoto mezinárodního sdružení spolu s československým vojskem v únoru 1919. Organizace YMCA se zde zpočátku starala o vojenské domovy, kterých bylo na Slovensku v letech 1919 až 1921 zhruba dvacet. ${ }^{2}$ V letech 1922 a 1923 pak armáda postupně převzala spravované objekty a zařízení organizace YMCA do vlastní správy. ${ }^{3}$

Kromě této tzv. Vojenské YMCA působila v Bratislavě také Železničářská a Poštovní YMCA, která zde byla založena 24. června $1920 .^{4}$

Nedlouho po př́chodu YMCA do Bratislavy se zde objevil nápad postavit její samostatnou budovu (viz obrázek 1). K tomu nutně musely být vyřešeny dvě podmínky, a to získání vhodného pozemku a zabezpečení financí na stavbu.

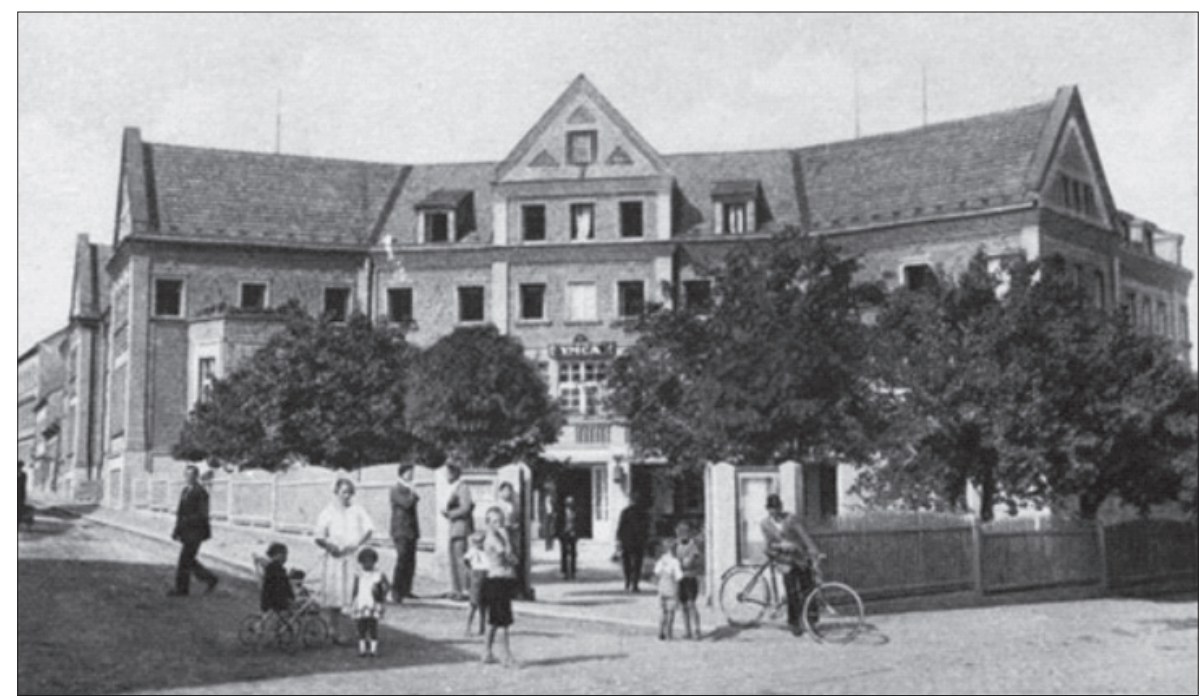

Obrázek 1: Pohlednice s motivem bratislavské YMCA

V březnu 1920 přijel ze Spojených států amerických do Bratislavy zástupce americké YMCA R. L. Dilley, jehož úkolem bylo vyřešit ony dva problémy. Bratislavská YMCA měla velké štěstí, že jí pozemek za velice výhodných podmínek nabídl Juraj von Schulpe. Tento pozemek se nacházel na rohu Karpatské a Šancové ulice. O finanční stránku se alespoň zpočátku postarala americká

\footnotetext{
${ }^{1}$ Pravděpodobně se jedná o „Křestanský spolek mladíkư“ („Křestanské sdružení mládeže“), prostřednictvím kterého organizace YMCA působila na území pozdějšího Československa ve druhé polovině 19. století. YMCA na Slovensku. (b.r.). Dostupné 27. záři 2010, z http://www.ymca.sk/historia.php

${ }^{2}$ Perútka J. et al. (1967). Športy na Slovensku. Bratislava: Šport, s. 219.

${ }^{3}$ Slovenský národný archív. Fond Policajného riaditel'stva Mat 15/32.

${ }^{4}$ Vojenský historický archiv. Fond Ministerstvo národní obrany - presidium. roč. 1918-1923. Karton 28, č.j. 3866. Presidium ministerstva železnic Republiky Československé Ministerstvu národní obrany v Praze dne 5. dubna 1921.
} 
YMCA, která přispěla na úvod částkou 5 milionů korun. Československý stát navíc slíbil sdružení YMCA podporu ve výši $40 \%$ nákladů.

Budova bratislavské YMCA se pak stala druhou nejdražší budovou YMCA v Československu. Byla otevřena velice záhy, a to 8 . prosince $1923 .{ }^{5}$ Do té doby však museli sportovci místního sdružení využivat pouze nejbližší okoli či útroby stavěné budovy. ${ }^{6}$

V letech 1923-1929 se pak výdaje na její dostavení a vybavení vyšplhaly na částku přesahující 13,5 milionu korun. Také v tomto případě byla většina nákladů zaplacena Američany, kteří vypomohli částkou, jejíž hodnota přesáhla 8,5 milionu korun. ${ }^{?}$

Až do roku 1926 však bylo členstvo bratislavské YMCA nuceno pro pěstování tělesné výchovy a sportu využívat pouze malou tělocvičnu, ve které často hrálo např. házenou. V létě používali sportovci YMCA prázdná stavební místa nedaleko své budovy, kde mohli se svolením majitelů hrát basketbal či volejbal. ${ }^{8}$

K počátkům „skutečného“ rozvoje tělesné výchovy a sportu zde došlo až v roce 1927, když byla dostavena přístavba budovy na Šancové ulici, jejíž stavba započala v roce 1926, a ve které se nacházela velká tělocvična, která byla určena především pro sportovní hry. Její dostavení mělo zcela zásadní význam pro další rozvoj tělesné výchovy a sportu v bratislavské YMCA, nebợ mj. výrazně přispělo ke vzniku nových sportovních odborů, a to např. gymnastického, šermířského a ping-pongového. ${ }^{9}$

\section{Nástin vývoje tělesné výchovy a sportu v bratislavské Akademické YMCA}

Členové místního sdružení zde však sportovali ještě před otevřením budovy. Tyto počátky je však nutno hledat ve spojitostí s jinou částí programu organizace YMCA. Již roku 1920 se snažila YMCA v Bratislavě organizovat první vzdělávací kurzy. Činnost posluchačů nově otevřené Univerzity Komenského v Bratislavě v rámci těchto kurzů dala také zřejmě podnět k založení místní Akademické YMCA, která pak byla významně zaměřena na tělesnou výchovu a sport. ${ }^{10}$ Akademická YMCA zde vznikla dne 29. března 1922 a již v prvním roce své činnosti založila volejbalový odbor, ${ }^{11}$ čím také velice přispěla k rozvoji a rozšíření tohoto sportu v Bratislavě.

Kromě volejbalového vznikl v rámci Akademické YMCA také odbor boxerský, basketbalový, fotbalový, šermířský či atletický. Akademická YMCA dosáhla v Bratislavě svého vrcholu v letech 1922-1924. Během této doby měla značnou zásluhu na budování hřišš v Medické zahradě, kde si prrišli na své hráči tenisu, basketbalu a volejbalu. Rovněž se pokusila o získání povolení na vybudování atletické dráhy. Její boxeři a šermíríi sváděli bitvy v ústř̌ední budově na Lorencově ulici, atleti a fotbalisti pak využivali hřiště I. ČsŠK (Československý športový klub). Akademická YMCA si rovněž od roku 1923 pronajímala hodiny v bazénu na Grösslingově ulici, kde organizovala plavecký výcvik, jehož se během prvního roku zúčastnilo zhruba 1200 zájemců. V roce 1924 byl ustanoven její plavecký odbor.

$\mathrm{Na}$ činnosti atletického odboru Akademické YMCA se značně podepisovaly přesuny hráčů z klubů do klubů. Jednotlivých soutěží se jeho členstvo účastnilo bez větších problémů do jara 1924. Poté nastala v Akademické YMCA krize. Některým studentům nevyhovoval tento klub z hlediska ideového, a tak si založili při katolickém studentském spolku „Sv. Svoráda“ lehkoatletickou sekci, do níž v roce 1924 odešla většina z členů Akademické YMCA. ${ }^{12} \mathrm{Z}$ tohoto spolku pak

\footnotetext{
${ }^{5}$ Národní archiv, Fond YMCA, č. kartonu 4, Sign. 4, Repairs, equipment and temporary quarters.

${ }^{6}$ Archiv YMCA Bratislava, YMCA na Slovensku - Povereníctvu pre veci vnútorné, odbor IV, dne 16. 5. 1945.

${ }^{7}$ Národní archiv, Fond YMCA, č. kartonu 2, sign. 6, Table of building expenses (local Y in ČSR - 1923-1929).

${ }^{8}$ YMCA (Časopis sdružení YMCA v Československu), IV., 1926, č. 1, s. 20-29.

${ }^{9}$ YMCA v Bratislave 1923-1933. (1933). Bratislava: Slovenská Grafia, s. 11-12.

${ }^{10}$ Perútka, J. (1980). Dejiny telesnej výchovy a športu na Slovensku. Bratislava: Šport, s. 76.

${ }^{11}$ Šarochová, K. (2013). YMCA a Vysokoškolský sport jako průkopníci volejbalu v Českých zemích. (Diplomová práce). Praha: Univerzita Karlova v Praze, s. 26.

${ }^{12}$ Sport, VI., 1926, č. 4.
} 
vznikl klub SŠKU (Slovenský športový klub Univerzita). Oba tyto kluby sice disponovaly dobrým materiálem, ale jejich velkým problémem bylo, že neměly vlastní atletickou dráhu. ${ }^{13} \mathrm{~V}$ roce 1928 se pak konal další odchod členů Akademické YMCA do nově založeného VŠB (Vysokoškolský šport Bratislava). ${ }^{14}$

Ve druhé polovině dvacátých let se začaly zprávy o tělovýchovné a sportovní činnosti bratislavské Akademické YMCA objevovat čím dál tím méně. Ta pravděpodobně od poloviny 20. let omezovala svou sportovní činnost a její členstvo tak zřejmě začalo vyhledávat tento druh možnosti trávení volného času v jiných sportovních klubech či v občanském sdružení YMCA.

Ze zápisu z posledního valného shromáždění je jasné, že od 12. prosince 1930 již Akademická YMCA nevyvíjela žádnou činnost. Oficiálně však byla zrušena až 5. února 1935. ${ }^{15}$

\section{Vývoj tělesné výchovy a sportu v občanském sdružení YMCA v Bratislavě}

Kromě př́islušníků Akademické YMCA však v Bratislavě pěstovali tělesnou výchovu a sport i členové občanského sdružení YMCA, kteří s Akademickou YMCA nutně nemuseli mít nic společného.

Poměrně značným problémem ale bylo, že bratislavské sdružení nemělo na počátku své tělovýchovné činnosti dostatek kvalitních vedoucích. Tento handicap se bratislavská YMCA snažila zmírnit uspořádáním instruktorských kurzů, na které pak pozvala přednášet jak československé, tak i zahraniční odborníky. ${ }^{16}$ Také díky nim pak členstvo bratislavské YMCA dosáhlo na řadu sportovních úspěchů. ${ }^{17}$

\section{Basketbal}

S organizací YMCA jsou na Slovenku spjaty počátky dnes velice populární „americké hry“ basketbalu. ${ }^{18}$ Historicky první zápas zde byl odehrán v Žilině roku 1919, kde tuto hru předvedli američtí sportovní lektoři. První pravidla pak vydali zakladatel slovenského basketbalu Jan Kopal ${ }^{19}$ a ředitel pražské YMCA František Miloslav Marek.

J. Kopal, jehož domovem se roku 1921 stala Bratislava, kde se stal tajemníkem místního sdružení, zorganizoval pro „své“ basketbalové družstvo v Medické zahradě první basketbalový zápas v červnu $1922 .{ }^{20} \mathrm{~V}$ propagaci basketbalu pokračoval i v následujících letech. Do výroční zprávy sdružení YMCA z července roku 1924 pak o basketbalu napsal:

„Napriek tomu, že sme s basketbalom iba pred dvoma mesiacmi začali, hráva teraz v Bratislave 11 mužstiev, z ktorých sa 5 zúčastnilo turnaja o majstrovstvo, pričom vítazstvo dobylo 1. mužstvo YMCA - budova. Táto hra je pre nás neobyčajne rýchla, no získava si oblubu a rýchlo sa rozširuje. "21

\footnotetext{
${ }^{13}$ Slovenský národný archív. Fond Policajného riaditel'stva Mat 15/32.

${ }^{14}$ Budova YMCA v Bratislave a šport | budovaymca. (b.r.). Dostupné 20. duben 2014, z http://budova ymca.sk/2013/05/13/budova-ymca-v-bratislave-a-sport/

${ }^{15}$ Perútka, J. (1980). Dejiny telesnej výchovy a športu na Slovensku. Bratislava: Šport, s. 76.

${ }^{16}$ Mezi tyto instruktory patřil též olympijský vítěz v běhu na 100 metrů Charles „Charley“ William Paddock. Ten zde měl přednášku, ve které mj. vysvětloval teorii startu, běhu, skoku, dýchání a sportovního tréninku. Sport, III., 1923, č. 21, s. 7.

${ }^{17}$ YMCA v Bratislave 1923-1933. (1933). Bratislava: Slovenská Grafia, s. 48-51.

${ }^{18}$ Riess, L. W. (1923). Úkoly tělovýchovného odboru Ymky. YMCA (Časopis sdružení YMCA v Československu), 1(3), s. 65-68.

${ }^{19}$ J. Kopal se v roce 1924 rovněž postaral o vybudování sáńkařské a lyžařské dráhy v okolí Bratislavy, kterou mohla využivat veškerá místní mládež. Vedení dráhy a dozor nad ní byl svěřen do rukou YMCA. Marek, F. M. (1924). Přehled tělovýchovné činnosti za r. 1924. YMCA (Časopis sdružení YMCA v Československu), 2(5-6), s. 186-187.

${ }^{20}$ Sutaz. (b.r.). Dostupné 20. listopad 2013, z http://bscbratislava.sk/old/historia.htm

${ }^{21}$ Budova YMCA v Bratislave a šport | budovaymca. (b.r.). Dostupné 20. listopad 2013, z http://budovaymca.sk/2013/05/13/budova-ymca-v-bratislave-a-sport/
} 
Turnaj, o kterém J. Kopal napsal, se uskutečnil dne 19. července 1924 v divadelním sále budovy YMCA. Oněch pět zúčastněných družstev bylo z většiny složeno z členů organizace YMCA.

Ve finálovém zápase se utkala mužstva „Vůdcovský kurz modří“ a 1. mužstvo YMCA - budova. Zápas to byl poměrně pěkný, rychlý a někdy také ostrý. Bohužel pro diváky nepadlo př́liš košů. Zápas skončil 2:2 (1:0) a musel být prodlužován. Většina diváků před zápasem vůbec nepochybovala o vítězství „Vůdcovského kurzu“. Teprve v prodloužení, když došlo k „Zamíchání“ sestavy basketbalistů YMCA, si začali jednotliví hráči více vyhovovat. YMCA tak nakonec utkání ovládla $\mathrm{v}$ poměru $4: 10 .{ }^{22}$

K velkému rozmachu basketbalu v bratislavské YMCA došlo v roce 1927, když byla dokončena přístavba budovy místního sdružení, ve které se nacházela tělocvična (viz obrázek 2), do které mohla YMCA přenést své tréninky z Medické zahrady či dvora Reálného gymnázia sídlícího na Dunajské ulici. Za hezkého počasí se však basketbal hrál i nadále pod otevřeným nebem. ${ }^{23}$

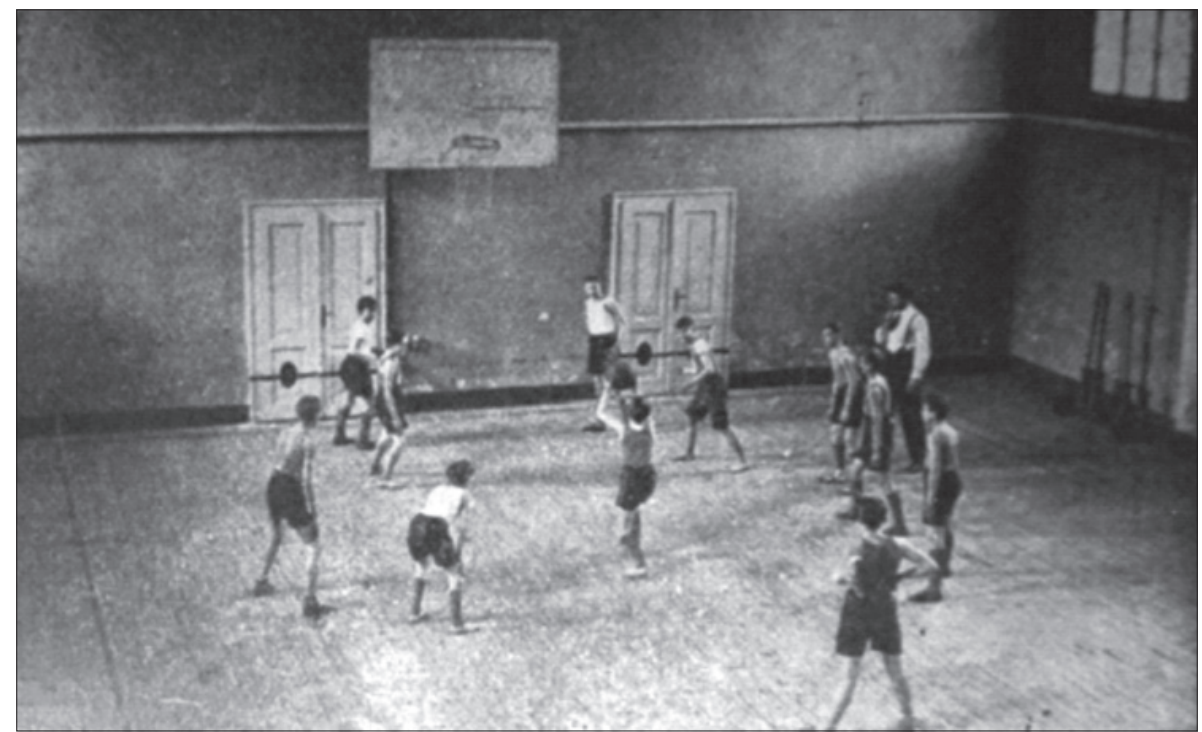

Obrázek 2: Basketbal v tělocvičně bratislavské YMCA v polovině 30. let

Vybudování tělocvičny v přístavbě budovy YMCA samozřejmě zapříčinilo vzrůst zájmu o basketbal, což pak přispělo rychlému nárůstu členské základny. Popularita této hry, především mezi studenty, byla tak veliká, že se zde začaly na konci 20. let utvářet, v rámci místního sdružení YMCA, basketbalové skupiny nesoucí názvy např. Uncas, Mohykáni, Amundsen, Cansas či Vinetou. ${ }^{24}$

První větší úspěch místních basketbalistů přišel v roce 1930, když na mistrovství organizace YMCA v Praze vybojovali třetí místo za domácím týmem a YMCA Banská Bystrica. ${ }^{25}$

Velice důležitý však pro ně byl navázaný kontakt s českými a moravskými hráči. Tento rok se také poprvé v československé historii bojovalo o titul basketbalového republikového mistra. YMCA Bratislava zde skončila na třetím místě. ${ }^{26}$

\footnotetext{
${ }^{22}$ Sport, IV., 1924, č. 31.

${ }^{23}$ Budova YMCA v Bratislave a šport | budovaymca. (b.r.). Dostupné 20. listopad 2013, z http://budovaymca.sk/2013/05/13/budova-ymca-v-bratislave-a-sport/

${ }^{24}$ Machajdík, I. (2013). Goly, body, priekopnici. Bratislavský kurier, 7(11), 12.

${ }^{25}$ STAR, roč. 1931, č. 45.

${ }^{26}$ Perútka, J. (1980). Dejiny telesnej výchovy a športu na Slovensku. Bratislava: Šport, s. 96.
} 
Roku 1933 si pak bratislavská YMCA připsala svá historicky první basketbalová vítězství nad brněnskými týmy. K nim přidala další výhry, a to např. nad Sokolem Nymburk. Tyto úspěchy opět přispěly k výraznému zvýšení zájmu o basketbal a poté i nárůstu členské základny.

Zájem byl tak veliký, že zde YMCA začala organizovat basketbalové kurzy určené jak pro mládež, tak i pro dospělé. Tyto kurzy se skládaly z praktické a teoretické části. Jejich součástí bývaly také zkoušky na rozhodčí.

Zvláště úspěšná byla YMCA Bratislava při práci s mladými basketbalisty. Ti si zde v této době opět začali zřizovat své kroužky s názvy: King, Byrd, Rádlov klub, Woodan, Hej rup, Albatros, Cansas či Yukon. Tyto kroužky ale velice rychle vznikaly, párovaly se, zanikaly, obnovovaly se, a to jak pod stejným, tak i pod jiným názvem. Sledování jejich vývoje je tudíž velice obtížné. Tito mladí hráči samozřejmě zpočátku neoplývali basketbalovým uměním. O tom svědčí také jeden z prvních zápasů mezi skupinami Vinetou a Blesk, který skončil 1:0. Nicméně pravidelným tréninkem výkonnost některých skupin rychle rostla. ${ }^{27}$

V roce 1934 se stali basketbalisté YMCA Bratislava mistry Slovenska, což jim zajistilo účast na závěrečném turnaji o mistra republiky, kam rovněž postoupila YMCA Praha a Sokol Královo Pole. Bratislavští basketbalisté se však po dvou porážkách umístili na třetím místě. ${ }^{28}$ Rozvoj basketbalu v Bratislavě totiž stále brzdil nedostatek rovnocenných soupeřu pro YMCA Bratislava. ${ }^{29}$

$\mathrm{V}$ budově bratislavské YMCA se rovněž konala historicky první konfrontace slovenského a rakouského basketbalu. V březnu 1935 zavítali do Bratislavy vídeňští basketbalisté, kteří se zde dvakrát střetli s domácím výběrem. ${ }^{30}$ Oba zápasy vyhráli domácí, a to v bodových poměrech $34: 11$ a $24: 19$.

Počínaje tímto rokem se v Bratislavě počala každoročně konat nová soutěž s názvem „Bratislavská basketbalová liga“. Její první ročník, kterého se zúčastnilo osm týmů: Blesk, Byrd, Cansas, Hviezda, King, Star, Uncas a Vinetou, se hrál dvoukolovým systémem „každý s každým“. Zúčastněné týmy musely na soupisku napsat minimálně sedm hráčů.

Historicky první ligový zápas se uskutečnil v tělocvičně YMCA dne 23. června 1935, když proti sobě nastoupila družstva Vinetou a King. Po „bezbodovém“ prvním poločase nakonec zvítězili hráči skupiny Vinetou, a to v poměru $7: 4$.

Zajímavé je, že zápas řídil Andrej Plávka, dříve poměrně známý slovenský básník a spisovatel, který přišel do Bratislavy v roce 1934. Zde přijal funkci tajemníka sdružení YMCA, ve kterém později působil jako basketbalový funkcionář, rozhodčí a organizátor. Byl to právě A. Pávka, kdo se stal jednou z hlavních postav Bratislavské basketbalové ligy.

První ročník, jehož celkové hodnocení předčilo všechna očekávání, ovládli hráči týmu Blesk. V následujících dvou ročnících se mistrem stala skupina Vinetou (viz obrázek 3). V ní se také objevily nové basketbalové hvězdy, kterými byli Herrmann, Matrac a Bobocký. ${ }^{31}$

\footnotetext{
${ }^{27}$ Machajdík, I. (2013). Goly, body, priekopnici. Bratislavský kurier, 7(11), 12.

${ }^{28}$ STAR, roč. 1934, č. 4.

${ }^{29}$ STAR, roč. 1932, č. 13.

${ }^{30}$ Zda šlo o bratislavský basketbalový výběr, či pouze hráče organizace YMCA, pramen neuvádí. Stejně tak neuvádí ani bližší informace o rakouském soupeři.

${ }^{31}$ Budova YMCA v Bratislave a šport | budovaymca. (b.r.). Dostupné 20. listopad 2013, z http://budovaymca.sk/2013/05/13/budova-ymca-v-bratislave-a-sport/
} 


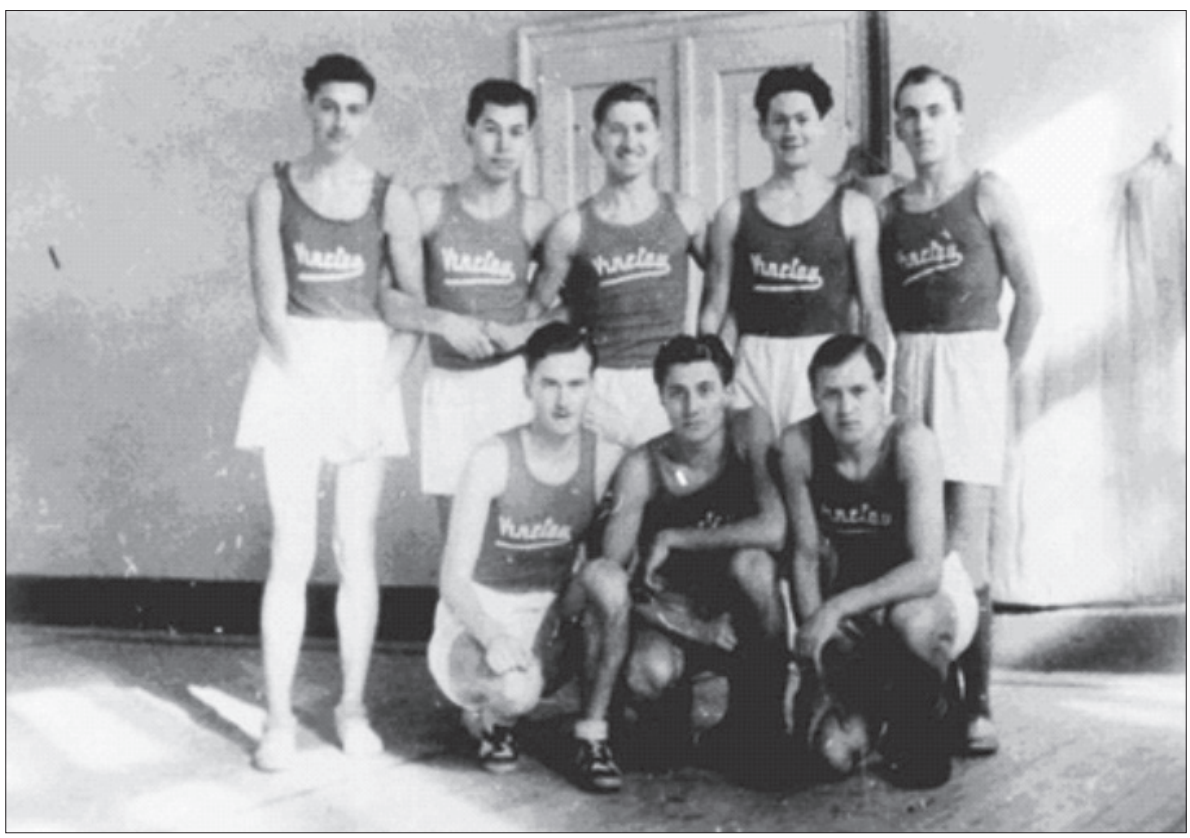

Obrázek 3: Skupina Vinetou - vítěz Bratislavské basketbalové ligy v sezónách 1936/1937 a 1937/1938

V roce 1935 obhájila bratislavská YMCA titul slovenského mistra a mohla se těšit na závěrečný republikový mistrovský turnaj, který ve dnech 13. a 14. dubna organizovala. V dopoledních hodinách druhého hracího dne oplatila YMCA Bratislava porážku Sokolu Královo Pole z minulého mistrovství. Na skvěle hrající basketbalisty YMCA Praha však bratislavští nestačili. Na turnaji tak vybojovali druhé místo. ${ }^{32}$

Bohužel se však také začaly pozvolna ozývat negativní hlasy, které kritizovaly úzké zaměření bratislavské YMCA právě na tento sport. Není však pravda, že by zde o ostatní sporty nebyl zájem. Velice populární zde byly také např̀. stolní tenis a volejbal.

O rok později vybojovala YMCA Bratislava v rámci republiky opět třetí místo. Turnaj se konal opět v Bratislavě a zvítězila v něm YMCA Praha před Sokolem Královo Pole. To byl ale pravděpodobně poslední velký úspěch basketbalistů bratislavské YMCA v meziválečném období. ${ }^{33}$ Jejím velkým poválečným úspěchem pak bylo, že dvě hvězdy skupiny Vinetou - Bobocký a Herrmann, ${ }^{34}$ byly členy vítězného československého týmu na mistrovství Evropy v roce 1946.

Box

Ve dvacátých letech se stal poměrně populárním bratislavským sportem také box. Jeho popularita sice v YMCA nikdy nedosáhla úrovně basketbalu, ale i tak se její borci účastnili několika místních utkání.

Dne 24. února 1924 uspořádali v Bratislavě místní práátelé boxu mítink, kterého se zúčastnilo pět dvojic. Boje nadšených boxerů sledovalo poměrně dost diváků, kteří takřka do posledního místa vyplnili Č́kyho tělocvičnu v Růžové ulici. Touhu zvítězit měl také Junek z YMCA Bratislava $(59$ kg), který nastoupil proti Zacharovi z ŠK Bratislava. Zápas diváky poměrně nadchl.

\footnotetext{
32 STAR, roč. 1935 , č. 16.

${ }^{33}$ STAR, roč. 1936, č. 39.

${ }^{34}$ Machajdík, I. (2013). Goly, body, priekopnici. Bratislavský kurier, 7(11), 12.
} 
Starší rutinér Junek však podlehl na body ambicióznímu Zacharovi, jehož vítězství bylo diváky bouřlivě príijato. ${ }^{35}$

Dne 27. února 1927 se v bratislavském kině „Adlon“ odehrál boxerský mítink, který pořádal místní PTE (Pozsonyi Torna Egyesület - Bratislavský tělocvičný spolek) a kterého se kromě československých boxerů zúčastnili též borci z Vídně a Pešti. Této akce se zúčastnil také Báše z YMCA Bratislava, který si přeměřil síly s Linnetzbergerem z AC (Athletic Club) Herkules Bratislava. Báše však svi̊j zápas prohrál na body. ${ }^{36}$

Ve dnech 3. a 4. března 1928 se v Bratislavě konalo boxerské mistrovství Slovenska. Organizováním turnaje byl pověřen Boxing Club Bratislava. Místní sdružení YMCA bylo jedním z prvních klubů, které organizátorům odeslaly závaznou přihlášku. ${ }^{37}$

S blížícím se koncem 20. let přestávali o sobě dávat boxeři z bratislavské YMCA vědět. Je tudíž pravděpodobné, že zde došlo k omezení činnosti boxerského kroužku nebo dokonce jeho zrušení.

\section{Lehká atletika}

Dalším sportem, který byl členy YMCA v Bratislavě hned z kraje 20. let pěstován, byla lehká atletika. Ta se stala sportem bratislavského sdružení již v dobách, kdy se zde YMCA starala o vojenské domovy. Velice známým se pak stal její každoroční běžecký závod Lamač - Bratislava, jehož první ročník se konal v roce 1922.

Značné popularity dosahovaly mezi členstvem YMCA také individuální i štafetové závody okolo budovy, které se zde pravidelně konaly od roku 1925. Místní YMCA rovněž přispěla k založení místního lehkoatletického okrsku ČsAAU (Československá amatérská atletická unie). ${ }^{38}$

Kromě oblíbených klubových závodů se bratislavská YMCA několikrát utkala také s dalšími atletickými týmy, mezi které patřil např. SK (Sportovní klub) Přerov, se kterým si YMCA přeměřila síly v létě 1926. Slovenský tým ale tentokrát nebyl zcela ve formě, nebot jeho členové se po ukončení školního roku atletice prríliš nevěnovali. Jediným atletem z YMCA, který zde vybojoval individuální první místo, byl Beneš, který zvítězil ve skoku vysokém i dalekém. YMCA pak také zvítězila ve štafetovém běhu na $4 \times 200$ metrů. Přerovští atleti tak vyhráli celé meziklubové utkání poměrně výrazným bodovým poměrem $64: 35 .{ }^{39}$

Atletická výkonnost bratislavské YMCA nebyla až tak vysoká. Její závodníci tak o sobě počínaje koncem 20. let př́iliš vědět nedávali. Jednou z mála výjimek byl Balcar, který v roce 1928 zaznamenal v trojskoku výkon 12,22 metru, což byl v Československu 10. nejdelší skok sezóny. ${ }^{40}$

YMCA se tak snažila atletické akce především pořádat. V neděli 12. května 1929 tak např. organizovala štafetové závody městem. O víkendu 1. a 2. června pak pořádala stř̌edoškolské lehkoatletické závody. ${ }^{41}$

Na počátku 30. let začala lehká atletika v bratislavské YMCA velmi upadat. ${ }^{42} \mathrm{~V}$ roce 1934 zaujala YMCA k atletice následující postoj: Lehká atletika je individuální sport, na který se může každý jednotlivec připravovat sám. ${ }^{43}$

\footnotetext{
${ }^{35}$ Sport, IV., 1924, č. 10.

${ }^{36}$ Sport, VII., 1927, č. 9, s. 8.

${ }^{37}$ Kolik boxerů YMCA přihlásila a jakých výsledků dosáhli, však pramen neuvádí. Sport, VIII., 1928, č. 8.

${ }^{38}$ YMCA v Bratislave 1923-1933. (1933). Bratislava: Slovenská Grafia, s. 47-50.

${ }^{39}$ Sport, VI., 1926, č. 32.

${ }^{40}$ STAR, 1928, č. 45 , s. 9.

${ }^{41}$ STAR, 1929, č. 17, s. 9.

${ }^{42}$ Ruch bratislavskej Ymky, IV., 1937, č. 2, s. 7.

${ }^{43}$ Ruch bratislavskej Ymky, I., 1934, č. 4-5, s. 10.
} 


\section{Plavání}

Velký kus práce udělala YMCA v již dřive zmíněném plavání. Její kurzy základů plavání organizované na počátku 20. let byly velice úspěšné. Vybraní plavci se pak zde od roku 1923 učili záchraně tonoucích. Tím se YMCA snažila předejít každoročním neštěstím na Dunaji.

Záchranu tonoucích YMCA také předváděla na ukázkových akcí, které sklidily obrovský obdiv. Měly dokonce takový úspěch, že byla YMCA policejním ředitelstvím požádána, aby záchraně tonoucích učila také policejní př́íslušníky (viz obrázek 4). Během několika let jich absolvovalo kolem 50. Policisté však byli učeni taktéž klasickému plavání.

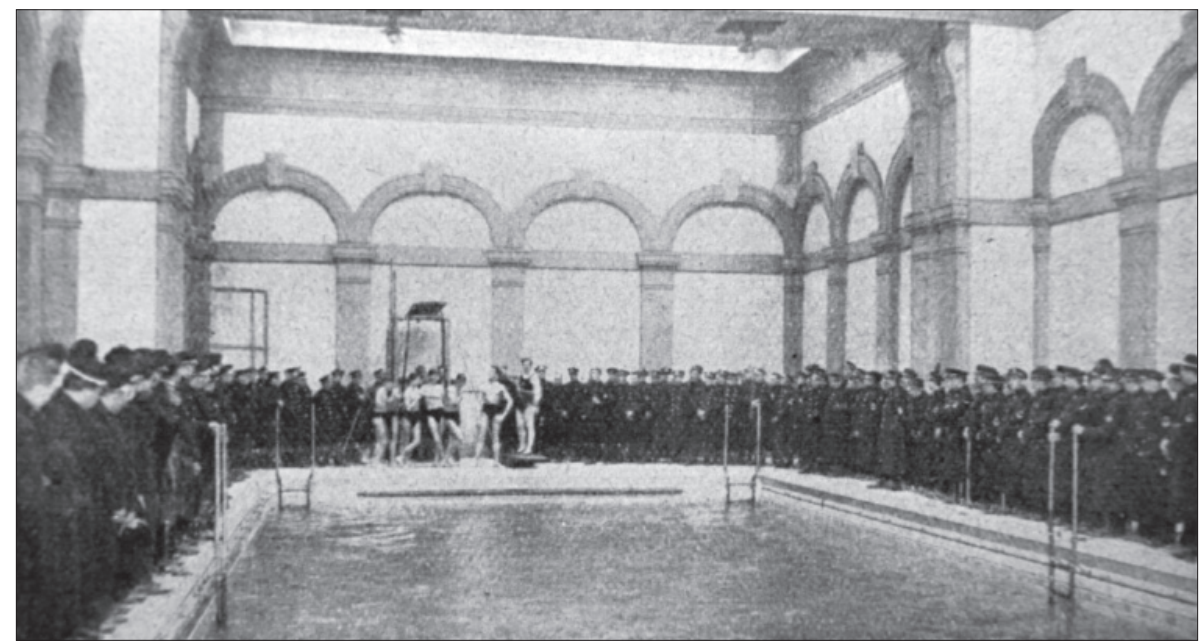

Obrázek 4: YMCA Bratislava a její vyučování záchrany tonoucích pro místní policejní sbor

V roce 1924 došlo kromě ustanovení plaveckého odboru Akademické YMCA také k založení plaveckého odboru YMCA, který stál mimo „akademiky“. Bratislavská YMCA rovněž stála u založení místní plavecké župy. Větších výsledků však na celoslovenské úrovni nedosahovala.

\section{Ragby}

Ve druhé polovině 20. let vznikl v bratislavské YMCA také ragbyový tým. Ten se pak dne 1. května 1928 utkal s místním ŠK Slavia Bratislava. Oba týmy nastoupily se svými náhradníky ${ }^{44}$ a doufaly ve vítězství. V zápase pak předváděly značnou vůli, se kterou se snažily podat co nejlepší možný výkon.

Ragbistům YMCA se dařilo především v útočné hře. YMCA měla řadu dobrých a snaživých hráčů, na které mohl být trenér Anýž opravdu hrdý. Mezi nimi vynikali především mladý Ludvík, Rudzan a Rosa. Ragbistům organizace YMCA ale chyběla pohotovost a celkový herní přehled. Slavia však bohužel pro ně dokázala těchto slabin velice dobře využít a zvítězila v poměru $21: 3.45$

Oba rivalové se v roce 1928 utkali celkem třikrát. Pokaždé odešli jako vítězové ragbisté ŠK Slavia Bratislava. ${ }^{46}$ To byly také jediné zápasy, které bratislavská YMCA v roce 1928 odehrála. Její celkové skóre pak bylo 6:153.47

Vzrůstající zájem o tento sport vedl v roce 1928 k založení nového svazu - „Československého svazu ragby - footballu“. YMCA Bratislava se stala jedním z osmi zakládajících členů. ${ }^{48}$

\footnotetext{
${ }^{44}$ Důvod, proč oba týmy postavily náhradníky a ne hráče základní sestavy, pramen neuvádí.

${ }^{45}$ STAR, roč. 1928, č. 21.

${ }^{46}$ STAR, roč. 1929 , č. 8.

${ }^{47}$ Almanach sportu na rok 1929-1930, roč. 1929-1930, s. 75.

${ }^{48}$ STAR, roč. 1928, č. 25, s. 11-12.
} 
Nevýrazné výkony jejích ragbistů ale pravděpodobně přispěly k tomu, že se již YMCA roku 1929 mistrovských utkání neúčastnila. ${ }^{49}$

\section{Stolní tenis}

Značně populárním sportem, který se zde pěstoval prakticky od otevření budovy v prosinci 1923, byl stolní tenis. Bratislavská YMCA se pak stala organizátorem mnohých turnajů, jako např́klad mistrovství Bratislavy, mistrovství západního Slovenska a řady dalších, at už celoslovenského či dokonce mezinárodního charakteru.

Stejně jako další sporty, byl i ping-pong v Bratislavě ovlivněn relativní blízkostí měst Vídeň, Budapešt a Praha, s jejichž stolními tenisty sváděli bratislavští hráči čas od času „ping-pongové bitvy“.

Nejlepším místním hráčem se stal v meziválečném období Karol Morávek, ${ }^{50}$ který postupně vystřídal kluby YMCA, PTE a ŠK Bratislava. ${ }^{51}$

První mezinárodní turnaj ve stolním tenisu na území Slovenska organizoval ve dnech 8.-11. prosince 1927 pod protektorátem ČsTTA (Československá Table - Tennisová Associace) právě TTC (Table - tenis Club) YMCA Bratislava. Na tuto akci, která se uskutečnila v budově YMCA, se přihlásila řada tuzemských i zahraničních hráčů. Představila se zde např́íklad řada skvělých stolních tenistů z Rakouska a Mad'arska. ${ }^{52}$

Další zajímavé utkání se v budově bratislavské YMCA uskutečnilo dne 11. března 1928, když sem zavítal k zápasu s domácími Wiener TTC. Utkání přineslo očekávané velké vítězství Vídeňanů. YMCA, za kterou zde hráli K. Morávek, Adelsberger, Čech, Kott a Hajnoczi, však převyšovala hosty především v obranné hře. Tu měli nejlépe propracovanou Adelsberger a K. Morávek. Bratislavští stolní tenisté navíc hráli velice obětavě, čímž si také vysloužili jedno vítězství. O to se postarala dvojice K. Morávek - Kott, která k překvapení všech porazila rakouský mistrovský pár Fehér - Fleischmann v pěti setech. Bratislavská YMCA tak celkově podlehla vídeňským stolním tenistům $\mathrm{v}$ poměru $24: 4 .{ }^{53}$

Velice přesvědčivou formu si hráči bratislavské YMCA drželi ve stolním tenisu až do roku 1932 (viz obrázek 5). Počínaje tímto rokem se zde YMCA dostala, především kvůli odchodu jejích nejlepších hráčů, do dvouleté herní krize. ${ }^{54}$

\footnotetext{
${ }^{49}$ Nová tělesná výchova, II., 1928/1929, č. 1-2, s. 89.

${ }^{50}$ Karol Morávek byl v letech 1926-1936 slovenskou hráčskou jedničkou. Mezi roky 1930 a 1933 byl dokonce československým reprezentantem. Jeho největším úspěchem bylo 5.-8. místo na mistrovství světa v roce 1932. ${ }^{51}$ Správy, novinky, oznamy | Slovensky športovy portal. (b.r.). Dostupné 20. listopad 2013, z http://sport. gov.sk/CMS/Document/Details/123

${ }^{52}$ STAR, roč. 1927, č. 49.

${ }^{53}$ Sport, VIII., 1928, č. 11.

${ }^{54}$ Budova YMCA v Bratislave a šport | budovaymca. (b.r.). Dostupné 20. listopad 2013, z http://budovaymca.sk/2013/05/13/budova-ymca-v-bratislave-a-sport/
} 


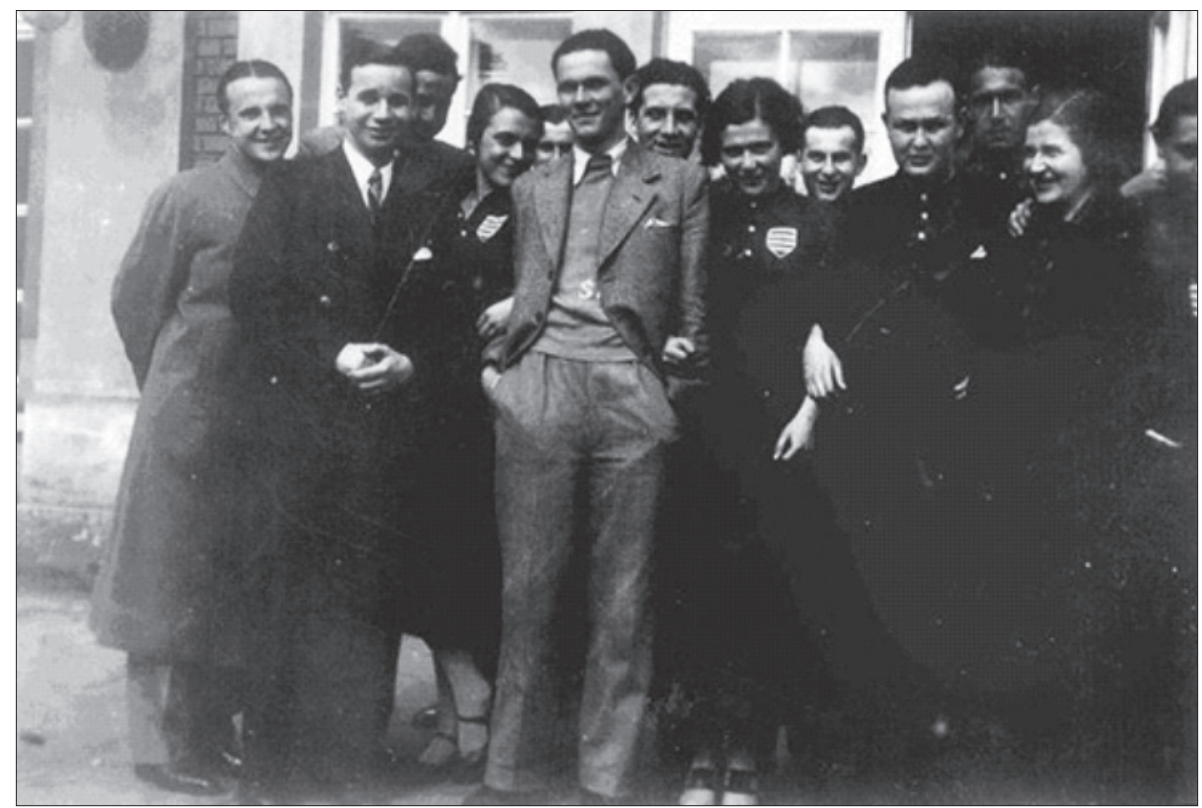

Obrázek 5: Stolní tenisté YMCA Bratislava a YMCA Banská Bystrica před budovou bratislavského sdružení roku 1932

Přesto nadále žila stolním tenisem. Koncem roku 1934 začali její hráči „chytat druhý dech“, i když na své dobré výsledky již nikdy zcela nenavázali. Následujícího roku se stala Bratislava, stejně jako v letech 1927 a 1932, hostitelem mistrovství Slovenska. Organizováním této akce byla pověřena právě místní YMCA.

Na turnaji se však nakonec představili i zahraniční hráči. Vítězem mužské dvouhry se stal Mad’ar Miklos Szabados, který byl mistrem světa z roku 1931 ve dvouhře, šestinásobný mistr světa ve čtyřhře a trojnásobný mistr světa ve smíšené čtyřrhře. ${ }^{55}$

Vzpomínku na staré úspěšné časy pak ještě oživil rok 1936, kdy se ve finále mistrovství Slovenska ve stolním tenisu střetla YMCA se svým někdejším velkým rivalem - PTE. YMCA však ve svých klubových místnostech těsně podlehla hostům v poměru zápasů $6: 7 .^{56}$

\section{Volejbal}

Již na počátku 20. let se v bratislavské YMCA začala pěstovat také druhá populární „americká hra“ - volejbal. V polovině 20. let se již YMCA pravidelně účastnila místních turnajů,, ${ }^{57} \mathrm{i}$ když k výraznému zpopularizování volejbalu opět došlo až po dokončení přístavby budovy místního sdružení.

Počínaje otevřením nové tělocvičny začala volejbalová úroveň hráčů bratislavské YMCA rychle stoupat (viz obrázek 6). V roce 1928 se již bratislavská YMCA stala na banskobystrickém turnaji poprvé volejbalovým mistrem Slovenska. ${ }^{58}$

\footnotetext{
${ }^{55}$ Siegman, J. M. (1992). The International Jewish Sports Hall of Fame. New York: SP Books, s. 160.

${ }^{56}$ Budova YMCA v Bratislave a šport | budovaymca. (b.r.). Dostupné 20. listopad 2013, z http://budovaymca.sk/2013/05/13/budova-ymca-v-bratislave-a-sport/

${ }^{57}$ Sport, V., 1925, č. 29.

${ }^{58}$ Zde se dostupné prameny liší. Perútka, J. (1982). Malá encyklopédia telesnej výchovy a športu. Bratislava: Šport, s. 602 uvádí, že toto byl historicky první turnaj o slovenského volejbalového mistra. Sport, V., 1925, č. 29 naopak uvádí, že první mistrovství Slovenska se konalo již v roce 1925.
} 


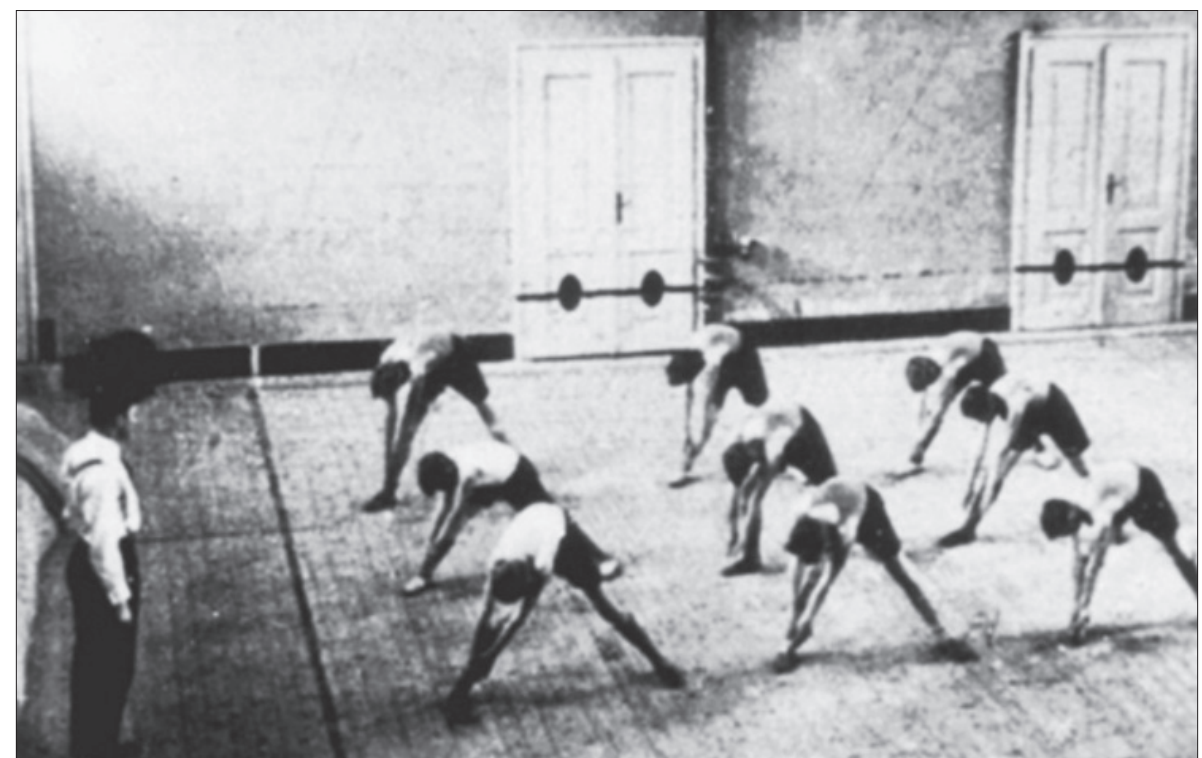

Obrázek 6: Rozcvička volejbalistů YMCA Bratislava v jejich tělocvičně

V listopadu 1930 se pak v Bratislavě uskutečnil do této doby největší slovenský volejbalový turnaj, na který se přihlásilo 16 družstev a který bratislavská YMCA rovněž vyhrála. Zde se již na výkonu hráčů značně projevovala výhoda vlastní tělocvičny, kde mohli bez problémů po celý rok trénovat. ${ }^{59}$

Ve dnech 19. a 20. záŕí 1931 se v Pardubicích konalo mistrovství republiky mužů a žen ve volejbalu. Volejbalisté a volejbalistky zde na šesti travnatých kurtech bojovali o ceny, které do turnaje věnovali František Smotlacha a firma Fotoservice. ${ }^{60}$ YMCA Bratislava, úřadující volejbalový mistr Slovenska, hrála ve třetí skupině, kde porazila tým Bata Zlín $2: 0$. Ve stejném poměru však podlehla Strakově akademii II i Sokolu Orlová. Do dalších bojů tak nepostoupila. Mistrem republiky se stali volejbalisté Strakovy akademie Praha. ${ }^{61}$

O dva roky později se YMCA Bratislava opět stala volejbalovým mistrem Slovenska a mohla se tak těšit na zápasy o mistra Československa. Tam však výraznějšího úspěchu opět nedobyla. ${ }^{62}$

V sezóně 1933/1934 se stala tělocvična bratislavské YMCA dějištěm zápasů místní nově založené zimní volejbalové ligy. Jejími premiérovými účastníky byly: YMCA, ŠK Úradnícky, VŠ, Reálka, kroužky MŠC (Malacký športový klub) Malacky či Senior. Ligový ŕád pak tuto soutěž charakterizoval následujícím způsobem:

„Volleyballová liga je založená preto, aby si hráči nášho mesta zachovali cez zimu formu a aby sa stálym stykom mužstiev zvýšila úroveň nášho volleyballu. Preto je prístupná všetkým registrovaným a neregistrovaným klubom. V registrovanom družstve smú hrat iba registrovaní hráči, v neregistrovanom iba neregistrovaní hráči. "“3

\footnotetext{
${ }^{59}$ Budova YMCA v Bratislave a šport | budovaymca. (b.r.). Dostupné 20. listopad 2013, z http://budovaymca.sk/2013/05/13/budova-ymca-v-bratislave-a-sport/

${ }^{60}$ STAR, roč. 1931, č. 39.

${ }^{61}$ Almanach sportu a tělesné výchovy na rok 1932, roč. 1932, s. 161.

${ }^{62}$ Almanach sportu a tělesné výchovy na rok 1933, roč. 1933, s. 143.

${ }^{63}$ Budova YMCA v Bratislave a šport | budovaymca. (b.r.). Dostupné 20. listopad 2013, z http://budovaymca.sk/2013/05/13/budova-ymca-v-bratislave-a-sport/
} 
Ve dnech 29. a 30. záŕí 1934 se na hřišti SK Bata Zlín utkalo 9 týmů, které svedly boj o titul republikového volejbalového mistra. YMCA Bratislava na úvod nestačila na VS (Vysokoškolský sport) Marathon Kladno, kterému podlehla 2:1. Své druhé utkání však volejbalisté bratislavské YMCA zvládli a zvítězili 2: 1 nad VŠB. Ve stejném poměru porazili i VS Strakova akademie. Čtvrtý zápas však volejbalistům YMCA nevyšel, nebot prohráli 2: 1 s pořádajícím týmem. YMCA se tak do finále neprobojovala a skončila na čtvrtém místě. Turnaj ovládli a republikovými mistry se tak stali volejbalisté VOS (Vysokoškolský odbor studentů) Praha. ${ }^{64}$

Na podzim roku 1935 bylo na hřišti nováčka ČVaBS - SK Slavia Praha uspořádáno dvoudenní volejbalové republikové mistrovství. Celé mistrovství ovládli zcela zaslouženě volejbalisté Sokola Plzeň V., kteří neprohráli ani zápas. Jediný zástupce organizace YMCA a zároveň slovenský volejbalový mistr - YMCA Bratislava (viz obrázek 7), ${ }^{65}$ jim podlehl $2: 0$. Ze sedmi týmů, které se na tento závěrečný volejbalový turnaj probojovaly, se YMCA umístila na posledním místě, když nevyhrála jediný zápas. ${ }^{66}$

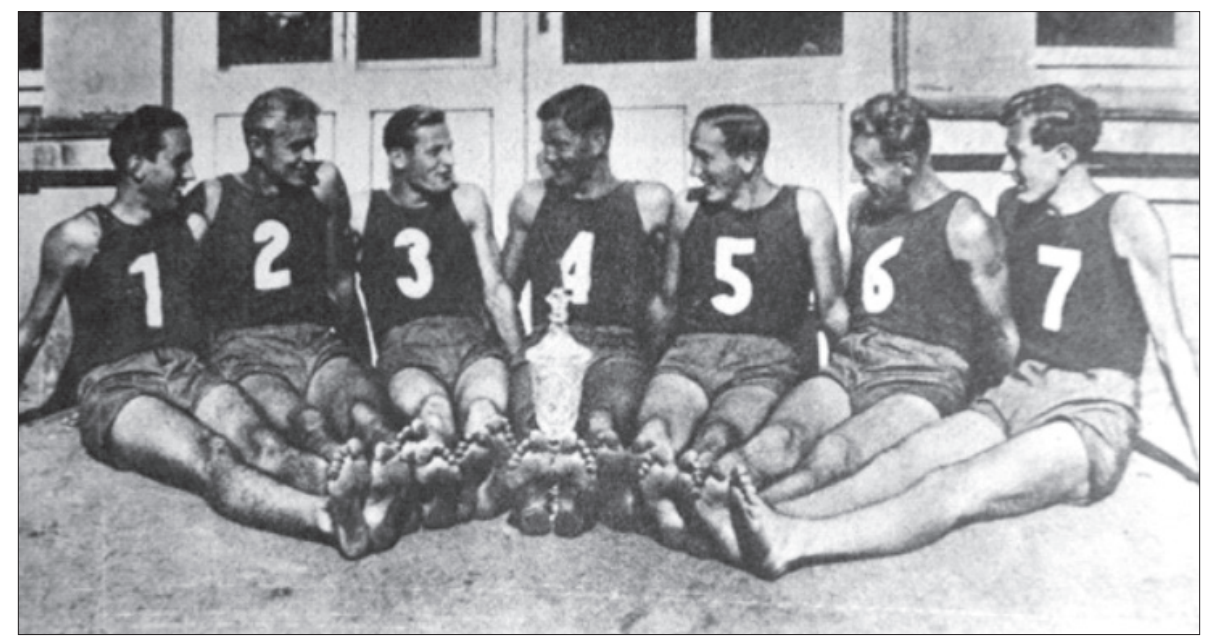

Obrázek 7: Volejbalisté YMCA Bratislava - mistři Slovenska pro rok 1935

Přestože se hráčům bratislavské YMCA nedařilo stát se republikovým mistrem, byl v tomto místním sdružení o volejbal nemalý zájem, což dokazuje i následující pasáž z měsíčníku Ruch bratislavskej Ymky z prosince 1935:

„Preplnená telocvičňa videla razantnú a vyrovnanú hru, kedy vítazstvo až do poslednej chvíle balansovalo na wolleyballovej sieti za nervózneho napätia divákov, kedy bombardéri Hapala, Valenta, Baltus, Selecký, Beneš a iní svojimi smečmi vedeli priviest' do varu a hurónskeho revu celý sál a bolo isté, že len vytrvalost’ a húževnatost' prinesie vítazstvo. "67

Obdobným způsobem se bratislavská YMCA prezentovala i následující rok. Opět vyhrála volejbalové mistrovství Slovenska a své dobré výsledky chtěla jistě potvrdit na mistrovství republiky, ${ }^{68}$ které se konalo na podzim 1936 na hřišti Sokola Bratislava.

\footnotetext{
${ }^{64}$ STAR, roč. 1934, č. 40.

${ }^{65}$ Almanach sportu a tělesné výchovy na rok 1936, roč. 1936, s. 138.

${ }^{66}$ STAR, roč. 1935, č. 40.

${ }^{67}$ Ruch bratislavskej Ymky, II., 1935, č. 12.

${ }^{68}$ Almanach sportu a tělesné výchovy na rok 1936, roč. 1936, s. 138.
} 
Na závěrečném turnaji se utkalo šest nejlepších republikových týmů o zisk putovního poháru a pozlacených medailí. Bratislavská YMCA měla poměrně houževnatý tým, který chtěl jistě odčinit zaváhání z minulého roku. Turnaj proběhl systémem „každý s každým“. Své vítězství si suverénně pohlídali hráči Sokola Kroměříž, kteří ani jednou nezaváhali. Volejbalisté bratislavské YMCA se nakonec umístili na čtvrtém místě, což byl pravděpodobně také jejich poslední velký výsledek v meziválečném období.

\section{Rozdělení československé YMCA}

S bližící se druhou světovou válkou začala být tělovýchovná a sportovní činnost bratislavské YMCA postupně omezována. Po vzniku samostatného Slovenského státu začali její členové pozvolna přecházet do konkurenčních klubů.

Slovenská YMCA se pak v období od vyhlášení autonomie Slovenské republiky v říjnu 1938 do vyhlášení samostatnosti Slovenska v březnu 1939 stala součástí konfederace autonomních částí - Česko-Slovenské YMCA. ${ }^{69}$

V červnu 1940 již fungovala jako samostatná organizace v suverénní Slovenské republice, kde vydala své vlastní stanovy, ve kterých přijala název „ÚSAK (Ústredie pre sociálnu a kultúrnu starostlivost') v Slovenskej republike“ se sídlem v Bratislavě, a ve kterých bylo uvedeno, že ÚSAK je právním nástupcem bratislavské YMCA. ${ }^{70}$ Důvod pro změnu názvu sdružení byl velice jednoduchý. V roce 1939 byla totiž organizace YMCA na Slovensku zakázána.

Po skončení druhé světové války došlo k obnovení činnosti organizace YMCA v Československu. Dne 2. listopadu 1946 zaregistrovalo tehdejší Ministerstvo vnitra nové stanovy slovenské YMCA, jejíž původní majetek jí byl převeden z rukou ÚSAK zpět. Obnovená československá YMCA však nebyla totožná s předválečnou, nebot na Slovensku byla obnovena jako „YMCA na Slovensku“. ${ }^{71}$

\section{ZÁVĚR}

Místní sdružení YMCA v Bratislavě významným způsobem přispělo k rozvoji, rozšíření a zpopularizování celé řady sportů, a to nejen na lokální, ale i na celoslovenské úrovni. Mezi tyto sporty patřily především volejbal a basketbal, ve kterých bratislavská YMCA v meziválečném období sklízela na Slovensku pravidelné úspěchy.

Její velkou výhodou byla vlastní budova, v jejiž přístavbě byla vybudována tělocvična, která byla vhodná pro pěstování těchto sportů. K většímu rozvoji basketbalu bohužel chyběli bratislavské YMCA na Slovensku silnější soupeři, se kterými by se mohla pravidelně utkávat. Přesto zde $\mathrm{v}$ rámci této organizace vzniklo v meziválečném období mnoho týmů, které se počínaje rokem 1935 účastnily Bratislavské basketbalové ligy.

Kromě „amerických her“ měla v tomto sdružení poměrně značný význam také lehká a těžká atletika nebo zde probíhající výuka plavání, v rámci které pak YMCA Bratislava rovněž školila zachránce tonoucích. Tím se snažila předejít každoročním neštěstím př̀i koupání v Dunaji.

Dále nelze opomenout ani silný klub stolního tenisu, jehož největší hvězdou byl bezesporu K. Morávek, který dokonce reprezentoval Československo na mistrovství světa.

Kromě těchto tradičních her, které v meziválečném Československu pěstovala celá řada místních sdružení YMCA, byl v bratislavské YMCA poměrně populární i jeden, pro tuto organizaci méně tradiční sport - ragby. Přestože ragby bylo v tomto sdružení pěstováno pouze krátkou dobu, stala se bratislavská YMCA jedním ze zakladatelů nového svazu - „Československého svazu ragby - footballu“.

\footnotetext{
${ }^{69}$ Národní archiv, fond YMCA, č. kartonu 1, sign. 1. Návrhy na reorganizaci YMCA v Česko-Slovensku.

${ }^{70}$ Národní archiv, fond YMCA, č. kartonu 1, sign. 1. Stanovy slovenské organizace YMCA.

${ }^{71}$ Sedliačik, I. (2004). Od začiatku po začiatok (Činnost' YMCA Banská Bystrica v rokoch 1919-1999). Banská Bystrica: YMCA, s. 6-8.
} 
Přes poměrně značnou členskou základnu a oblíbenost jednotlivých sportů začala bohužel bratislavská YMCA omezovat ve druhé polovině 30. let svou sportovní činnost. Na počátku druhé světové války se YMCA na Slovensku osamostatnila. Během ní pak došlo k jejímu zrušení. Po skončení války sice YMCA na Slovensku obnovila činnost, ale od původní československé YMCA se lišila. Byla totiž obnovena jako „YMCA na Slovensku“. ${ }^{22}$

\section{Literatura}

\section{Archivy}

Archiv hlavního města Prahy. Odbor vnitřních věcí. Spolkový katastr, sign. II/511. Československá YMCA. Karton 68. Archiv YMCA v Bratislavě.

Archiv YMCA v České republice.

Národní archiv. Fond YMCA. Kartony 1, 3, 5, 6.

Slovenský národný archív. Fond Policajného riaditel'stva.

Slovenský národný archív. Fond Ministerstva vnútra.

Vojenský historický archiv. Fond Ministerstvo národní obrany - presidium. roč. 1918-1923. Karton 28. č.j. 3866.

\section{Periodika}

Almanach sportu a tělesné výchovy, roč. 1923-1940.

Bratislavský kurier, roč. VII. (2013).

Nová tělesná výchova (List pro tělesnou výchovu, tělocvik, sport, hry, skauting a pro vědecké studium těchto oborů), roč. I. (1927/1928) - XI. (1938).

Ruch bratislavskej Ymky, roč. I. (1934) - IV. (1937).

Sport, roč. VII. (1927) - IX. (1929).

STAR, roč. 1926-1938.

YMCA (Časopis sdružení YMCA v Československu), roč. I. (1923) - IV. (1926).

\section{Tištěné prameny}

YMCA v Bratislave 1923-1933. (1933). Bratislava: Slovenská Grafia.

YMCA v prvním desetiletí 1921-1931. (1931). Praha: Vydavatelské oddělení YMCA.

\section{Literatura}

Bosák, E. a kol. (1969). Stručný přehled vývoje sportovních odvětvív Československu. Díl 1. Praha: Olympia.

Bureš, P. \& Plichta, J. (1931). Sport a tělesná kultura v Čsl. republice a cizině. Praha: Almanach sportu.

Černá, H. (2009). YMCA jako středisko výchovy mládeže v Československu 1919-1951. (Diplomová práce). České Budějovice: Jihočeská univerzita v Českých Budějovicích.

Johnson, E. L. (1979). The History of YMCA Physical Education. Chicago: Association Press.

Konečný, J. (1930). YMCA: její vznik, dějiny a význam. Praha: Československá akciová tiskárna.

Perútka, J. (1980). Dejiny telesnej výchovy a športu na Slovensku. Bratislava: Šport.

Perútka, J. et al. (1982). Malá encyklopédia telesnej výchovy a športu. Bratislava: Šport.

Perútka J. et al. (1967). Športy na Slovensku. Bratislava: Šport.

Sedliačik, I. (2004). Od začiatku po začiatok (Činnost'YMCA Banská Bystrica v rokoch 1919-1999). Banská Bystrica: YMCA.

Siegman, J. M. (1992). The International Jewish Sports Hall of Fame. New York: SP Books.

Šarochová, K. (2013). YMCA a Vysokoškolský sport jako průkopníci volejbalu v Českých zemích. (Diplomová práce). Praha: Univerzita Karlova v Praze.

Tlustý, T. \& Štumbauer, J. (2012). Tělesná výchova a sport v organizacích YMCA a YWCA v meziválečném Československu. České Budějovice: Jihočeská univerzita v Českých Budějovicích.

\section{Internet}

http://bscbratislava.sk/old/historia.htm

http://budovaymca.sk/2013/05/13/budova-ymca-v-bratislave-a-sport/

http://sport.gov.sk/CMS/Document/Details/123

http://www.ymca.sk/historia.php

\footnotetext{
${ }^{72}$ Slovenský národný archív. Fond Ministerstva vnútra - VC, č. 117 822/1940.
} 


\section{Seznam obrázků:}

Obrázek 1. Pohlednice s motivem bratislavské YMCA

Obrázek 2. Basketbal v tělocvičně bratislavské YMCA v polovině 30 . let. ${ }^{73}$

Obrázek 3. Skupina Vinetou - vítěz Bratislavské basketbalové ligy v sezónách 1936/1937 a 1937/1938.74

Obrázek 4. YMCA Bratislava a její vyučování záchrany tonoucích pro místní policejní sbor. ${ }^{75}$

Obrázek 5. Stolní tenisté YMCA Bratislava a YMCA Banská Bystrica před budovou bratislavského sdružení roku $1932 .{ }^{76}$

Obrázek 6. Rozcvička volejbalistů YMCA Bratislava v jejich tělocvičně. ${ }^{77}$

Obrázek 7. Volejbalisté YMCA Bratislava - mistři Slovenska pro rok $1935 .{ }^{78}$

${ }^{73}$ YMCA v Bratislave 1923-1933. (1933). Bratislava: Slovenská Grafia, s. 51.

${ }^{74}$ Budova YMCA v Bratislave a šport | budovaymca. (b.r.). Dostupné 20. duben 2014, z http://budovaymca. sk/2013/05/13/budova-ymca-v-bratislave-a-sport/

${ }^{75}$ YMCA (Časopis sdružení YMCA v Československu), I., 1923, č. 3.

${ }^{76}$ Budova YMCA v Bratislave a šport | budovaymca. (b.r.). Dostupné 20. duben 2014, z http://budovaymca. sk/2013/05/13/budova-ymca-v-bratislave-a-sport/

${ }^{77}$ YMCA v Bratislave 1923-1933. (1933). Bratislava: Slovenská Grafia, s. 49.

${ }^{78}$ STAR, 1935, č. 41. 